North American Journal of Fisheries Management, 1998, v.18, n.4, p.822-831. http://afs.allenpress.com/archive/1548-8675/18/4/pdf/i1548-8675-18-4-822.pdf DOI: 10.1577/1548-8675(1998)018<0822:ASETEP>2.0.CO;2

0275-5947

(C) Copyright by the American Fisheries Society 1998 
North American Journal of Fisheries Management 18:822-831, 1998

(C) Copyright by the American Fisheries Society 1998

\title{
Allocating Sampling Effort to Equalize Precision of Electrofishing Catch per Unit Effort
}

\author{
Mark W. Kershner ${ }^{1}$ and Elizabeth A. Marschall** \\ Aquatic Ecology Laboratory, Department of Zoology, The Ohio State University \\ 1314 Kinnear Road, Columbus, Ohio 43212-1194, USA
}

\begin{abstract}
We used a spatially explicit simulation model to examine the effects of lake shoreline length and lakewide fish density on electrofishing catch-per-unit-effort (CPUE) estimates of fish density. We also tested model predictions regarding the influence of shoreline length and fish density on precision of CPUE estimates by analyzing electrofishing data from Ohio reservoirs for juvenile gizzard shad Dorosoma cepedianum, which is a schooling fish, and largemouth bass Micropterus salmoides, a more solitary fish. Our goals were to estimate the impact of these factors on variability associated with population estimates derived from CPUE and to determine how these factors influence the minimum number of transects required to sample populations with a reliable degree of precision. Neither "minimum transect number" (number of transects sampled per lake in which all of 10 replicate simulations provided density estimates within $\pm 10 \%$ of the mean) nor "minimum variance" (variance among estimates given 20 transects/estimate) were affected by the size of lake being sampled. However, minimum transect number decreased with lakewide fish density, and minimum variance increased with fish density, particularly when fish were patchily distributed. Our results show that it is reasonable to choose one effort level (i.e., a constant number of transects per lake) for a variety of systems. This constant level of effort can achieve acceptable precision in systems differing in lake shoreline length, fish density, and fish patchiness, except in those systems having extremely low overall fish densities. In this case, more transects may be required.
\end{abstract}

The accuracy and precision of fish population estimates determines one's ability to separate variability resulting from sampling error from true population fluctuations (Fiedler 1978). The goal of most sampling is to obtain useful, accurate, and precise estimates with the least amount of effort for a given sampling method (Boxrucker et al. 1995; Miranda et al. 1996). Precision may also be affected by the spatial distribution of the population (location and size of fish patches) and the variability associated with the sampling method (Fiedler 1978; Miranda et al. 1996).

Electrofishing is commonly used to sample and assess fish population size and species composition in lakes, reservoirs, rivers, and streams (Hardin and Connor 1992). The efficacy of this sampling technique is directly influenced by water clarity, conductivity, depth, and temperature and by fish size, species, abundance, and distribution (Reynolds 1984). Catch per unit effort (CPUE) may vary among electrofishing samples within a lake because of heterogeneous fish distributions associated with differences in habitat structure or diurnal movement (Reynolds 1984). Thus, CPUE estimates based on few samples may not have suf-

\footnotetext{
* Corresponding author: marschall.2@osu.edu

${ }^{1}$ Present address: Department of Fisheries and Wildlife, Utah State University, Logan, Utah 84322-5255, USA.
}

ficient precision to provide reliable indices of population size. Several field studies have demonstrated the feasibility of developing regression models to estimate inshore fish density from electrofishing CPUE data (e.g., for fingerling and yearling walleyes Stizostedion vitreum: Serns 1982, 1983; for largemouth bass Micropterus salmoides: Hall 1986; Coble 1992; Buynak and Mitchell 1993; McInerny and Degan 1993); however, these studies did not examine electrofishing CPUE as a variable (among-transect) quantity (Hardin and Connor 1992).

In this study, we used a spatially explicit simulation model to examine the effects of lake shoreline length and lakewide fish density (number $/ \mathrm{m}^{3}$ ) on the precision of electrofishing CPUE estimates and minimum sample size. In building the model, it became clear that, even in the simplest model, it was important to consider fish density within a school (which is related to the number and size of schools making up the lakewide population) and sampling efficiency. Previous simulation studies of hydroacoustic estimates of fish abundance found that the patchy distribution of fish schools was an important source of error in population estimates (Fiedler 1978; Kimura and Lemberg 1981). Thus, we also incorporated fish density within a school and sampling efficiency into this 
simulation effort. These simulations also allowed us to address the problem of how to allocate effort to obtain accurate estimates with comparable levels of precision so as to detect differences between population means across systems or time periods. Lastly, we used electrofishing CPUE data from Ohio reservoirs to test model predictions regarding the influence of shoreline length and fish density on the precision of CPUE estimates. We used data from largemouth bass, which are generally solitary, and gizzard shad Dorosoma cepedianum, which generally form schools.

\section{Methods}

Simulation analyses of electrofishing CPUE.We simulated the sampling effort of an electrofishing boat in a spatially explicit fashion by constructing hypothetical lakes that differed in shoreline length, lakewide fish density, density of fish within a school (packing density), and sampling efficiency. Each hypothetical lake was represented by a grid of $2-\mathrm{m} \times 2-\mathrm{m}$ cells. Lake shoreline lengths were $3,200 \mathrm{~m}, 6,400 \mathrm{~m}, 12,800 \mathrm{~m}$, and $25,600 \mathrm{~m}$. Treatments for lakewide fish density were $2,5,10,15,20$, and $25 \mathrm{fish} / \mathrm{m}^{3}$. Fish school packing density was characterized as $5,15,25,35$, and $50 \mathrm{fish} / \mathrm{m}^{3}$ (within the range estimated for threadfin shad $D$. petenense; Schael et al. 1995). Lastly, sampling efficiency was characterized as either constant $(25 \%)$ or variable.

Lake shoreline length characterized the length of the matrix; total shoreline length was divided into $2-\mathrm{m}$ cells. The potential sampling area for the electrofishing boat extended eight cells $(16 \mathrm{~m})$ from shore. For example, a lake with a 3,200 m shoreline was represented by a matrix measuring 1,600 cells by 8 cells.

The size of a simulated lake's fish population and the number of schools within a lake were calculated as functions of lake surface area (i.e., potential sampling area), cell surface area, lakewide fish density, and school packing density. The number of fish in the lake was calculated by multiplying lake surface area by the lakewide fish density. The number of fish in a cell having fish was calculated by multiplying cell area by packing density within a cell. Finally, the number of fish schools in the lake was calculated by dividing the total number of fish in the lake by the number of fish in a cell. Individual fish schools were randomly assigned (with the subroutine RAN2; Press et al. 1989) to individual cells within the grid, which produced minimum school sizes equal to the size of a cell. At high lakewide fish densities, adjacent cells often contained fish, resulting in schools larger than one cell in area. All fish schools were assumed to be within $1 \mathrm{~m}$ of the water surface (Van Den Avyle et al. 1995) and to be identical with respect to the proportion of fish recruited to electrofishing gear. We also assumed that fish density did not vary from inshore to offshore.

For a given lake shoreline length and lakewide fish density, packing density represented different levels of patchiness of fish distribution within the lake. High packing densities indicated high levels of patchiness; low packing densities indicated a more homogeneous distribution of fish. Not all combinations of parameters were possible. For example, we could not combine low packing densities with high lakewide fish densities, as this resulted in a greater number of schools than there were cells to place them in. Our packing densities represented estimates from electrofishing surveys (E. Lewis, Ohio Division of Wildlife, M. Bremigan, Michigan State University, and J. Dettmers, Illinois Natural History Survey, personal communications) and hydroacoustic sampling (Schael et al. 1995; Vondracek and Degan 1995) for shad. However, more solitary fish may have packing densities lower than the lowest values used in our simulations.

Overall, we believe that fish distributions resulting from our choice of parameters were appropriate for simulating patchily distributed fish. For a given simulated lake, characterized by a given lakewide fish density-packing density combination, fish distributions were highly clumped, with mean: variance ratios much lower than 1.0 (range $=0.005-0.115$ ). As packing density and lakewide shoreline length increased, resulting fish distributions became more highly clumped (i.e., the mean: variance ratio declined). As lakewide fish density increased for a given packing density, mean : variance ratios increased; however, fish distributions remained highly clumped.

Sampling efficiency was incorporated into simulations as either constant or variable. If simulations were run at constant sampling efficiency, the electrofishing boat sampled $25 \%$ of the fish in the schools along all transects. In variable sampling efficiency runs, each school was randomly assigned an efficiency at which it would be sampled, ranging from $10 \%$ to $35 \%$. For simulating variable efficiency, the number of schools sampled at a given efficiency was adjusted such that the mean sampling efficiency was $25 \%$. Thus, the difference between the constant and variable efficiency simulations could be attributed to differences in vari- 
ability alone, not confounded by differences in mean efficiency. We believe that our estimates of constant $(25 \%)$ and variable (10-35\%) sampling efficiency are conservative based upon electrofishing surveys for patchily distributed gizzard shad. However, we expect more uniformly distributed fish species to have higher sampling efficiencies than we simulated.

The simulated electrofishing boat had a 2-m sampling width and a 1-m sampling depth. Individual electrofishing transects were $200 \mathrm{~m}$ long (100 cells) and did not overlap. To examine the effect of electrofishing effort (number of transects) on CPUE estimates of fish density, we varied the number of transects per sample from 1 to a maximum of 25 . We limited total sample area to half of the total shoreline area. Thus, for lakes with 3,200-m shorelines, transect number ranged from 1 to 10 ; for lakes with 6,400-m shorelines, transect number ranged from 1 to 20 ; and for lakes with either $12,800-\mathrm{m}$ or $25,600-\mathrm{m}$ shorelines, transect number ranged from 1 to 25 . For each number of transects, we ran 10 "replicate" simulations, which consisted of model runs that used identical variable values but different random-number seeds (with subroutine RAN2; Press et al. 1989). Random numbers controlled the precise location of fish within a given lake and the sampling efficiency in a given school of fish in the variable-efficiency treatments (see description above).

Variance among the 10 replicate estimates of CPUE for each combination of variables decreased with increasing number of transects and reached an asymptote by 20 transects in all cases. Thus, we characterized (a posteriori) the variance at 20 transects as the "minimum variance" (except in the case of the 3,200-m shoreline, in which we used 10 transects), where the variance leveled to an apparent asymptote. We also determined the minimum number of transects (minimum transect number) in which $100 \%$ of the replicate runs were within $\pm 10 \%$ of the mean for those 10 runs. We consider $\pm 10 \%$ to be an acceptable level of precision; given the variability observed in typical electrofishing surveys, we could not expect greater precision.

Data were analyzed by analysis of variance (ANOVA). Given that data were results of computer simulations rather than actual field sampling (and thus there is no limit on potential error degrees of freedom), we did not use the ANOVA to produce $P$-values on which to base conclusions about significance. Rather, type III sums of squares were used to compare the relative importance of each factor in contributing to the total variance of the simulation output.

Rather than using common types of distributions (e.g., normal, negative binomial, etc.) to simplify representation of potential estimates of CPUE, we simulated distributions resulting from typical electrofishing sampling techniques. We believe that we can more directly illustrate cause-and-effect relationships through simulation modeling than through an approach based upon analytical statistical models (e.g., model-based estimation: Hansen et al. 1983; Pennington 1983; Smith 1990).

Field analyses of electrofishing CPUE.-To verify results of the simulation analyses, we analyzed field electrofishing CPUE data (from Ohio reservoirs) for adult largemouth bass and juvenile gizzard shad, two species differing in packing density and likelihood of schooling. Adult largemouth bass tend to be solitary, and juvenile gizzard shad tend to school. Adult largemouth bass CPUE data were taken from electrofishing transects (range = 5-15 transects/reservoir-sample date combination) sampled in 13 Ohio reservoirs on 21 separate occasions during 1995 and 1996. Transects were approximately $500 \mathrm{~m}$ in length and were sampled with an electrofishing boat (pulsed-DC, 5-7-A). Juvenile gizzard shad CPUE data were taken from electrofishing transects (range $=16-22$ transects/ reservoir-sample date combination) sampled in nine Ohio reservoirs on 26 separate occasions during 1993 and 1994. Transects were approximately $200 \mathrm{~m}$ in length and were sampled with an electrofishing boat (pulsed-DC, 5-7-A).

We used field data to construct sample distributions to ask how our estimates of fish density would have changed if we had sampled different numbers of transects (i.e., used a different amount of effort) in the field. For each fish species, we calculated the number of fish captured $/ \mathrm{m}^{2}$ for each transect and used the resulting CPUE estimates to construct sample distributions for individual reservoir-sample date combinations. For each level of sampling effort $E$ (i.e., $E=$ total number of transects $=1,2, \ldots 25$ ), for each reservoir-sample date CPUE distribution, we randomly drew $E$ samples (with replacement) and estimated reservoir fish density from these $E$ samples. We made 10 replicate estimates for each combination of $E$, reservoir, and sample date for each species. Minimum variance was then calculated for each reservoir-sample date combination with CPUE estimates at 20 transects, as per the rationale and procedures outlined in the methods for the simulation analysis. We chose to use a sample size of 10 rep- 

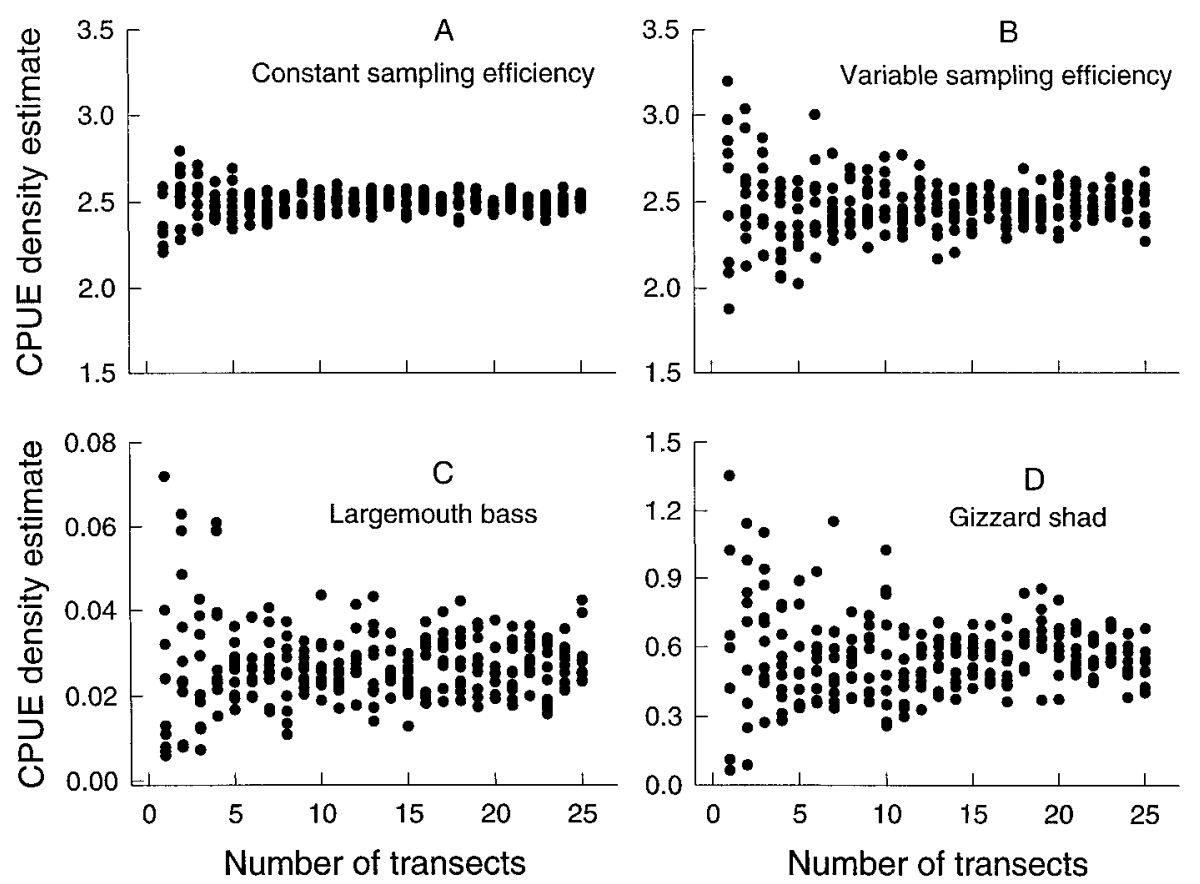

FigURE 1.-Estimates of catch per unit effort (CPUE) from simulations of lakes with a shoreline length of 25,600 $\mathrm{m}$, lakewide fish density of $10 / \mathrm{m}^{3}$, and packing density of $25 / \mathrm{m}^{3}$ as a function of the number of transects sampled at (A) constant and (B) variable sampling efficiencies. Also shown are estimates of CPUE from resampled field estimates as a function of electrofishing transects for (C) largemouth bass (Tappan Reservoir, 1995; Ohio Department of Natural Resources, Division of Wildlife) and (D) gizzard shad (C. J. Brown Reservoir, 1993; M. Bremigan, Michigan State University). Note that $y$-axis scales differ among these four plots.

licate estimates so that minimum variance estimates from field data were based upon the same sample size as simulation estimates of minimum variance. Thus, the effects of shoreline length and fish density on field estimates of minimum variance could be compared with predictions generated by simulation analyses.

\section{Results}

\section{Simulation Analyses of Electrofishing CPUE}

As the number of transects sampled increased, CPUE estimates converged toward the population estimate for the hypothetical system (Figure 1A, B). Variability in CPUE at low effort (i.e., low transect number) was higher with variable sampling efficiency than with constant sampling efficiency; however, this difference decreased as effort increased (Figure 1A, B). These qualitative patterns were the same for all variable combinations.

Minimum transect number.-The minimum number of transects required for all 10 replicates to be within $\pm 10 \%$ of the mean fish density generally decreased as lakewide fish density increased
(Figure 2; Table 1). At densities below 5 fish $/ \mathrm{m}^{3}$, fewer than 10 transects were generally required for $100 \%$ of the estimates to be within $\pm 10 \%$ of the mean. Lake size had little effect on this index (Figure 2; Table 1). The minimum number of transects required was highest at high packing densities and low lakewide fish density. Relative to lakewide fish density and packing density, variability of sampling efficiency and lake shoreline length had little influence on minimum transect number (Table 1).

Minimum variance.-Lake shoreline length had little effect on minimum variance (Figure 3; Table 2). Though minimum variance was higher for small lakes (i.e., 3,200-m shorelines) than large lakes (Figure 3), this was probably because variance was estimated at 10 rather than 20 transects for these smaller lakes. For larger lakes, the percent of total variation explained by lake shoreline length was only $1.6 \%$, rather than $10.1 \%$ for all lakes, indicating that lake shoreline length was not an important factor (Table 2). When fish were patchily distributed (high packing densities), minimum variance increased with increasing lakewide 


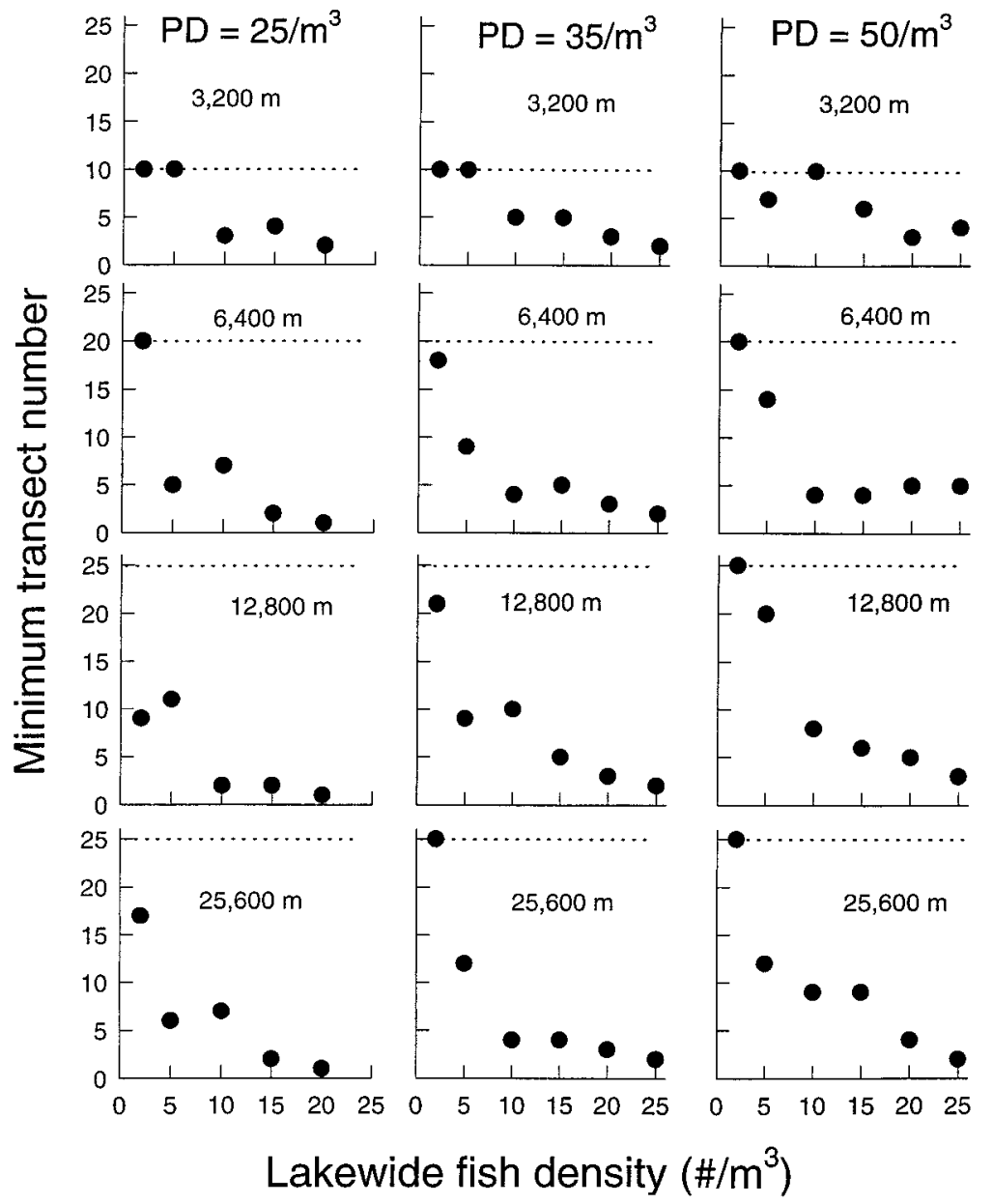

FigURE 2.-Minimum transect number required to produce estimates within $\pm 10 \%$ of the mean as a function of lakewide fish density for four lake shoreline lengths (increasing from top to bottom panel) and three representative packing densities (PD) from simulations having constant sampling efficiencies. Dashed lines represent the maximum number of transects used for a given lake size.

fish density, but when fish were less patchily distributed, there was no effect of lakewide fish density (Figure 3). Relative to lakewide fish density and packing density, variability of sampling efficiency and lake shoreline length had little influence on minimum variance (Table 2). The interaction between lakewide fish density and packing density accounted for $17 \%$ of the variation.

\section{Field Analyses of Electrofishing CPUE}

As measured by the coefficient of variation (CV $=100 \times \mathrm{SD} /$ mean), adult largemouth bass and juvenile gizzard shad differed in the heterogeneity associated with their spatial distribution. Across all reservoir-sample dates, largemouth bass had lower CVs (mean $\mathrm{CV}=52$, range $=19-101)$ than did gizzard shad (mean $\mathrm{CV}=174$, range $=$ 66-288). We interpret this difference to mean that gizzard shad were more patchily distributed than largemouth bass within Ohio reservoirs.

As the number of transects sampled from the distribution of field estimates of CPUE increased, the variability associated with replicate estimates of the mean number of fish $/ \mathrm{m}^{2}$ stabilized in all systems (Figure 1C, D); qualitative patterns for other combinations of reservoir and sample date were the same. Simulations incorporating variable sampling efficiency were qualitatively similar to resampled field data (Figure 1). Qualitative patterns were similar for all combinations of species, reservoir, and sample date.

Analyses of field data indicated that the mean 
TABLE 1.-Analysis of variance table for minimum transect number as a function of variability in sampling efficiency, fish packing density within a school, lake shoreline length, lakewide fish density, and the pairwise interactions of lakewide fish density with shoreline length and packing density. Percent of total type III variation is calculated by dividing the partial sums of squares (type III) by the sum of these partial sums of squares.

\begin{tabular}{lrrr}
\hline & & $\begin{array}{c}\text { Type III } \\
\text { sums of } \\
\text { squares }\end{array}$ & $\begin{array}{c}\text { Percent } \\
\text { of total } \\
\text { type iii } \\
\text { variation }\end{array}$ \\
\hline Sampling efficiency & df & 37 & 0.6 \\
Packing density & 4 & 1,734 & 27.3 \\
Shoreline length & 3 & 119 & 1.9 \\
$\quad$ Lakewide fish density & 5 & 4,119 & 64.9 \\
$\quad \begin{array}{l}\text { Shoreline length } \times \text { lakewide fish } \\
\quad \text { density }\end{array}$ & 15 & 305 & 4.8 \\
$\quad$ Lakewide fish density $\times$ packing & 11 & 34 & 0.5 \\
$\quad$ density & & & \\
$\quad$ Sum of type III sums of squares & & 6,348 & \\
\hline
\end{tabular}

among-transect density of largemouth bass, characterized by "low" packing densities, was less strongly related to minimum variance (Figure 4A) than the mean among-transect density of gizzard shad, characterized by "high" packing densities (Figure 4B). In field analyses of largemouth bass CPUE, minimum variance was highest and most variable for lakes with shorelines less than 10,000 $\mathrm{m}$ but remained low and varied less for lakes with shorelines greater than 10,000 m (Figure 4C). In contrast, lake shoreline length had no effect on the magnitude or variability of minimum variance for gizzard shad (Figure 4D).

\section{Discussion}

Minimum transect number was highest in systems with low lakewide fish density and high packing density. Under these conditions, the high degree of patchiness associated with school location resulted in reduced encounter rates between the simulated electrofishing boat and fish schools, a result common to models of sampling patchy resources. With increased lakewide fish density and reduced packing density, the encounter rate between the simulated electrofishing boat and fish schools increased. This resulted from a reduced level of patchiness and, correspondingly, produced a lower minimum transect number. In an empirical study of largemouth bass sampling, Miranda et al. (1996) also found that the number of samples required to reach a given level of precision increased as catch per hour (an indicator of lakewide fish density) decreased and that lake size (as estimated by shoreline length) had little effect on minimum transect number. Similarly, previous studies found that stream length does not significantly influence the effort required to reduce interreplicate variance of CPUE estimates (Lyons 1992; Paller 1995).

Estimates of minimum transect number from our modeling effort compared favorably with empirical estimates from a field study examining factors affecting CPUE estimates for largemouth bass in small homogeneous lakes (Hardin and Connor 1992). They estimated that between 4 and 27 transects were required to achieve $\pm 10 \%$ error, based on an $80 \%$ confidence interval. From our model, minimum transect number for small lakes fell within this range across a wide range of both fish and packing densities.

Simulation estimates of minimum variance increased as lakewide fish density and school packing density increased, further demonstrating the influence of patchiness. Our simulation results provide evidence that different lake conditions may cause different levels of baseline variance. If lakewide fish densities differ among lakes and packing densities differ among species, then electrofishing CPUE for different lakes and species should have different minimum variances. Because variance is influenced by fish density and fish species, we cannot expect equal variances across different lakes simply by altering sampling effort. However, our results suggest that we can obtain similar levels of precision for CPUE estimates from lakes differing in size, allowing for among-system comparisons of mean CPUE.

Although choosing sampling regimes that equalize variance in estimates among different systems may not be possible, choosing one sampling regime that will ensure acceptable precision in a variety of systems is quite possible. Except at very low fish densities, our simulated sampling achieved acceptable precision (100\% of estimates within $\pm 10 \%$ of mean) with about 10 transects. Thus, we are confident in choosing some constant transect number for systems that differed in size and fish density, unless we suspect that overall fish density is extremely low in a particular system. In these cases, we would need to increase effort accordingly.

Given its substantial influence on electrofishing CPUE estimates, we require a better understanding of packing density and its relationship with schooling behavior. Packing density is probably a function of both biotic and abiotic variables, such as water temperature, turbidity, time of day, food availability, and species-specific behavior (Von- 


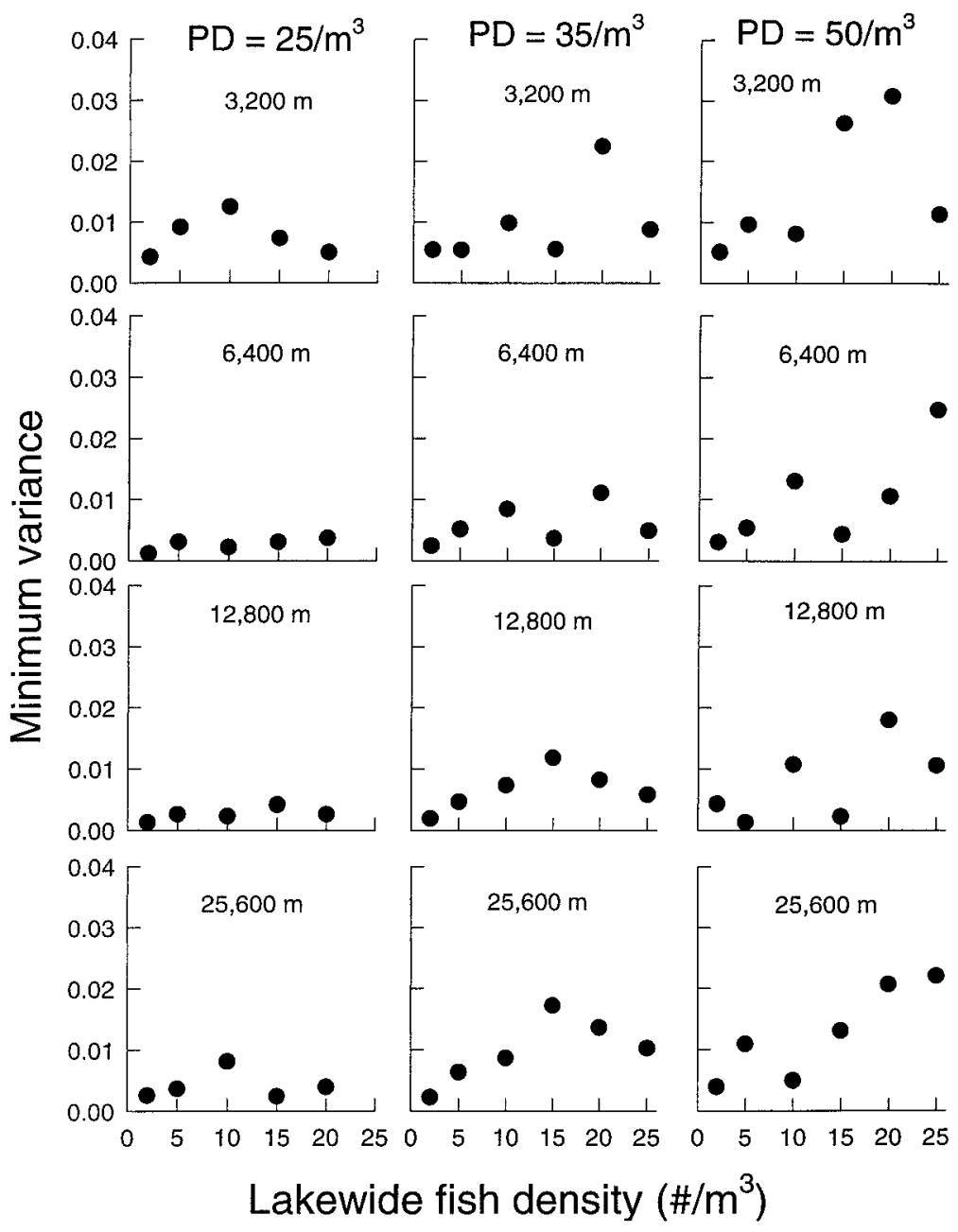

FIGURE 3.-Minimum variance as a function of lakewide fish density for four lake shoreline lengths (increasing from top to bottom panel) and three representative packing densities (PD) from simulations having constant sampling efficiencies.

dracek and Degan 1995). Thus, when individual species are targeted for electrofishing, understanding schooling behavior would allow for more accurate interpretations of the resulting data (Schael et al. 1995).

Effects of schooling on CPUE estimates have also been observed in other studies. Peterson and Rabeni (1995) found that schooling stream fishes had more highly variable estimates of biomass than nonschooling fishes, and Paller (1995) found that CPUE variance was greater for schooling than nonschooling stream fishes. Fiedler (1978) simulated the influence of patchiness in school groups of northern anchovy Engraulis mordax on the precision of hydroacoustic estimates of northern an- chovy population size. The patchy distribution of school groups proved to be an important source of error in population estimates (Fiedler 1978; Kimura and Lemberg 1981).

Analyses of CPUE data from Ohio reservoirs demonstrated that gizzard shad were more patchily distributed (based on their higher coefficients of variation) than largemouth bass. As predicted, minimum variance was more positively related to the density of schooling gizzard shad than to the density of nonschooling largemouth bass. Similarly, lake shoreline length was not related to the minimum variance of gizzard shad. Minimum variance of largemouth bass was consistently low, except in reservoirs with shorelines less than 10,000 
TABLE 2.-Analysis of variance table for minimum variance as a function of variability in sampling efficiency, fish packing density within a school, lake shoreline length, lakewide fish density, and the pairwise interactions of lakewide fish density with shoreline length and packing density. Percent of total type III variation is calculated by dividing the partial sums of squares (type III) by the sum of these partial sums of squares.

\begin{tabular}{|c|c|c|c|c|c|c|}
\hline \multirow[b]{2}{*}{ Source of variation } & \multicolumn{2}{|c|}{ df } & \multicolumn{2}{|c|}{$\begin{array}{c}\text { Type III } \\
\text { sums of squares }\end{array}$} & \multicolumn{2}{|c|}{$\begin{array}{l}\text { Percent of total } \\
\text { type III variation }\end{array}$} \\
\hline & All lakes & $\begin{array}{l}\text { Lakes } \\
>3,200 \mathrm{~m}^{\mathrm{a}}\end{array}$ & All lakes & $\begin{array}{l}\text { Lakes } \\
>3,200 \mathrm{~m}^{\mathrm{a}}\end{array}$ & All lakes & $\begin{array}{c}\text { Lakes } \\
>3,200 \mathrm{~m}\end{array}$ \\
\hline Sampling efficiency & 1 & 1 & $1.3 \times 10^{-4}$ & $0.7 \times 10^{-4}$ & 2.5 & 2.6 \\
\hline Packing density & 4 & 4 & $17.6 \times 10^{-4}$ & $9.8 \times 10^{-4}$ & 33.3 & 34.6 \\
\hline Shoreline length & 3 & 2 & $5.3 \times 10^{-4}$ & $0.4 \times 10^{-4}$ & 10.1 & 1.6 \\
\hline Lakewide fish density & 5 & 5 & $17.9 \times 10^{-4}$ & $11.8 \times 10^{-4}$ & 33.9 & 41.6 \\
\hline $\begin{array}{l}\text { Shoreline length } \times \\
\text { lakewide fish density }\end{array}$ & 15 & 10 & $2.1 \times 10^{-4}$ & $0.8 \times 10^{-4}$ & 3.9 & 2.7 \\
\hline $\begin{array}{l}\text { Lakewide fish density } \times \\
\text { packing density }\end{array}$ & 11 & 11 & $8.6 \times 10^{-4}$ & $4.8 \times 10^{-4}$ & 16.3 & 16.9 \\
\hline $\begin{array}{l}\text { Sum of type III sums } \\
\text { of squares }\end{array}$ & & & $52.8 \times 10^{-4}$ & $28.3 \times 10^{-4}$ & & \\
\hline
\end{tabular}

${ }^{a}$ Shoreline length.

$\mathrm{m}$ in length. In these smaller reservoirs, minimum variance varied widely, suggesting that a given level of precision may not be achievable for largemouth bass in these smaller systems.

Electrofishing sampling efficiency is affected by a variety of abiotic factors, such as water clarity, water depth, water temperature, and shoreline structure (Reynolds 1984). Peterson and Rabeni
(1995) found a significant negative relationship between the coefficient of variation and the variability associated with sampling efficiency, primarily resulting from physical habitat characteristics. In our simulations, we assumed that variable sampling efficiency was produced by these abiotic factors and found that variable sampling efficiency did not have a large effect on either minimum tran-

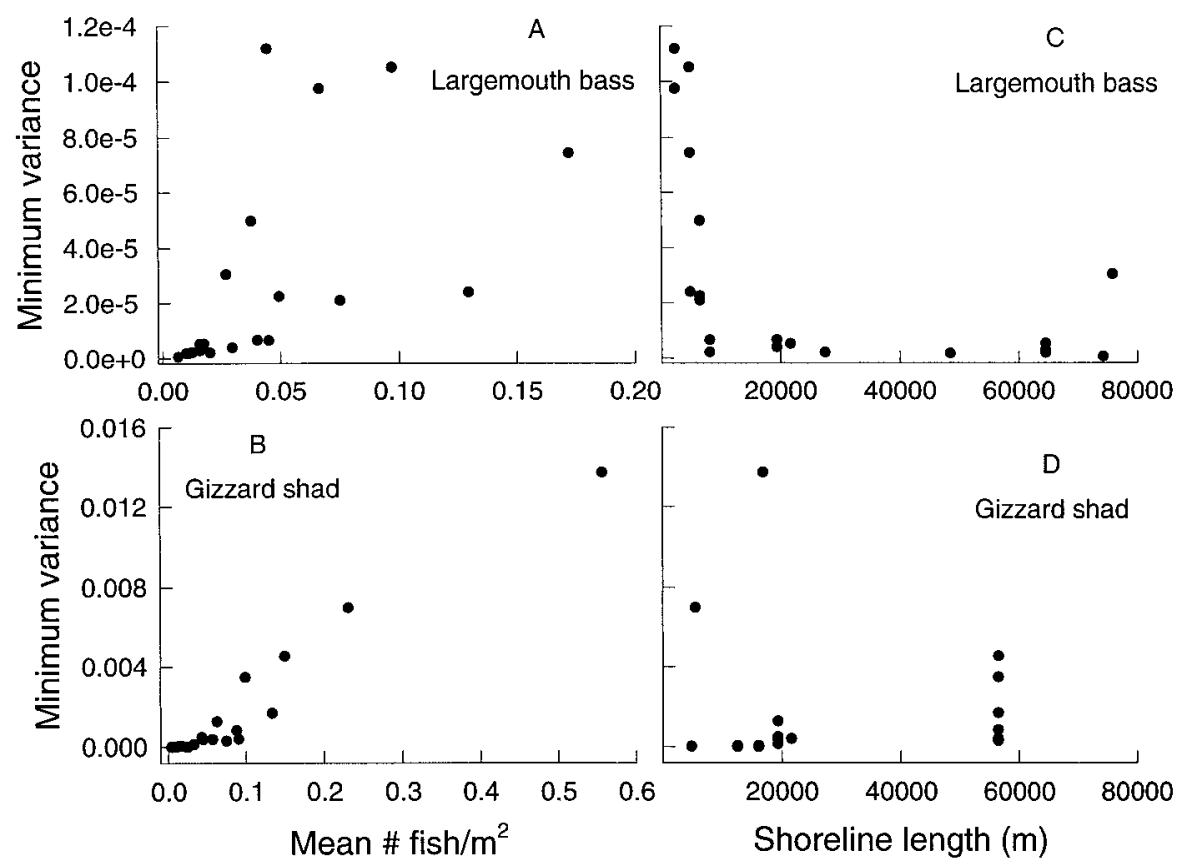

FIGURE 4.-The relationship between estimates of minimum variance derived from resampling field data and both mean number of fish $/ \mathrm{m}^{2}$ and shoreline length for $(\mathbf{A}, \mathbf{C})$ largemouth bass and $(\mathbf{B}, \mathbf{D})$ gizzard shad. Note that axis scales differ between plots for largemouth bass and gizzard shad. 
sect number or minimum variance within the range tested. Variability associated with sampling efficiency may also be influenced by the experience, technique, and efficiency of the electrofishing crew. Our simulations assumed that sampling was done by a single, experienced crew. However, Hardin and Connor (1992) found that differences in sampling efficiency among different crews (in the same systems and under similar environmental conditions) resulted in significant differences in electrofishing estimates of fish abundance and size structure.

In this study, lake shoreline length did not affect minimum sampling variance; thus, adequate sample sizes (i.e., number of transects) can be obtained in large systems with reasonable effort. The minimum number of transects required to achieve precision of $\pm 10 \%$ decreased as lakewide fish density increased. Minimum variance increased as fish density increased, particularly when fish were patchily distributed. Thus, higher packing densities will generally cause higher levels of variability in CPUE estimates. With the importance of packing density, hydroacoustic surveys (e.g., Schael et al. 1995; Vondracek and Degan 1995) should be used to provide better estimates of this factor. Variability in sampling efficiency, which is generally a problem, can be conquered with adequate sample size; however, the cost of additional effort must also be considered in these decisions. Although variance of CPUE estimates differs among lakes, similar levels of precision can be obtained among these same systems by using a common sampling regime. Ultimately, this allows comparisons across systems and also allows sampling in a lake not previously sampled based on data from other lakes in that region. Finally, simulation modeling should be considered as a tool when studying systems and ideas that are difficult to manipulate empirically because they are either too large or too complex for cost-effective experiments (Marschall and Roche 1998).

\section{Acknowledgments}

We thank Jeff Tyler for advice regarding statistical procedures. Ed Lewis and John Dettmers provided useful advice on the design of the simulated electrofishing boat. We thank Mary Bremigan for allowing us to use gizzard shad electrofishing data she collected in multiple lakes. We also thank Tom Hall and the Ohio Department of Natural Resources, Division of Wildlife, for allowing us to use largemouth bass electrofishing data collected in multiple lakes. Helpful reviews of previous drafts of this manuscript were provided by Mary Bremigan, David Cook, Jim Garvey, Gene Gilliland, Scott Hale, Mike Hansen, Jeff Tyler, and three anonymous reviewers. Support for this project was provided by Federal Aid in Sport Fish Restoration, project F-69-P, administered jointly by the U.S. Fish and Wildlife Service and the Ohio Division of Wildlife, and by the Department of Zoology, Ohio State University.

\section{References}

Boxrucker, J., P. J. Michaletz, M. J. Van Den Avyle, and B. Vondracek. 1995. Overview of gear evaluation study for sampling gizzard shad and threadfin shad populations in reservoirs. North American Journal of Fisheries Management 15:885-890.

Buynak, G. L., and B. Mitchell. 1993. Electrofishing catch per effort as a predictor of largemouth bass abundance and angler catch in Taylorsville Lake, Kentucky. North American Journal of Fisheries Management 13:630-633.

Coble, D. W. 1992. Predicting population density of largemouth bass from electrofishing catch per effort. North American Journal of Fisheries Management 12:650-652.

Fiedler, P. C. 1978. The precision of simulated transect surveys on northern anchovy, Engraulis mordax, school groups. Fishery Bulletin 76:679-685.

Hall, T. J. 1986. Electrofishing catch per hour as an indicator of largemouth bass density in Ohio impoundments. North American Journal of Fisheries Management 6:397-400.

Hansen, M. H., W. G. Madow, and B. J. Tepping. 1983. An evaluation of model-dependent and probabilitysampling inferences in sample surveys. Journal of the American Statistical Association 78:776-793.

Hardin, S., and L. L. Connor. 1992. Variability of electrofishing crew efficiency, and sampling requirements for estimating reliable catch rates. North American Journal of Fisheries Management 12: 612-617.

Kimura, D. K., and N. A. Lemberg. 1981. Variability of line intercept density estimates (a simulation study of the variance of hydroacoustic biomass estimates). Canadian Journal of Fisheries and Aquatic Sciences 38:1141-1152.

Lyons, J. 1992. The length of stream to sample with a towed electrofishing unit when fish species richness is estimated. North American Journal of Fisheries Management 12:198-203.

Marschall, E. A., and B. M. Roche. 1998. Using models to enhance the value of information from observations and experiments. Pages 281-297 in W. J. Resetarits and J. Bernardo, editors. Experimental ecology: issues and perspectives. Oxford University Press, New York.

McInerny, M. C., and D. J. Degan. 1993. Electrofishing catch rates as an index of largemouth bass population density in two large reservoirs. North American Journal of Fisheries Management 13:223-228. 
Miranda, L. E., W. D. Hubbard, S. Sangare, and T. Holman. 1996. Optimizing electrofishing sample duration for estimating relative abundance of largemouth bass in reservoirs. North American Journal of Fisheries Management 16:324-331.

Paller, M. H. 1995. Interreplicate variance and statistical power of electrofishing data from low-gradient streams in the southeastern United States. North American Journal of Fisheries Management 15: 542-550.

Pennington, M. 1983. Efficient estimators of abundance, for fish and plankton surveys. Biometrics 39:281286.

Peterson, J. T., and C. F. Rabeni. 1995. Optimizing sampling effort for sampling warmwater stream fish communities. North American Journal of Fisheries Management 15:528-541.

Press, W. H., B. P. Flannery, S. A. Teukolsky, and W. T. Vetterling. 1989. Numerical recipes: the art of scientific computing (FORTRAN version). Cambridge University Press, New York.

Reynolds, J. B. 1984. Electrofishing. Pages 147-163 in L. A. Neilsen and D. L. Johnson, editors. Fisheries techniques. American Fisheries Society, Bethesda, Maryland.

Schael, D. M., J. A. Rice, and D. J. Degan. 1995. Spatial and temporal distribution of threadfin shad in a southeastern reservoir. Transactions of the American Fisheries Society 124:804-812.

Serns, S. L. 1982. Relationship of walleye fingerling density and electrofishing catch per effort in northern Wisconsin lakes. North American Journal of Fisheries Management 2:38-44.

Serns, S. L. 1983. Relationship between electrofishing catch per effort and density of walleye yearlings. North American Journal of Fisheries Management 3:451-452.

Smith, S. J. 1990. Use of statistical models for the estimation of abundance from groundfish trawl survey data. Canadian Journal of Fisheries and Aquatic Sciences 47:894-903.

Van Den Avyle, M. J., G. R. Ploskey, and P. W. Bettoli. 1995. Evaluation of gill-net sampling for estimating abundance and length frequency of reservoir shad populations. North American Journal of Fisheries Management 15:898-917.

Vondracek, B., and D. J. Degan. 1995. Among- and within-transect variability in estimates of shad abundance made with hydroacoustics. North American Journal of Fisheries Management 15:933-939.

Received September 15, 1997 Accepted April 29, 1998 